https://helda.helsinki.fi

\title{
European Fantacy of the Arctic Region and the Rise of Indigenous Sámi Voices in the global Arena
}

\section{Toivanen, Reetta Johanna}

Springer International Publishing AG

2019-04-04

Toivanen , R J 2019 , European Fantacy of the Arctic Region and the Rise of Indigenous

Sámi Voices in the global Arena . in N Sellheim, Y V Zaika \& I Kelman (eds), Arctic

Triumph : Northern Innovation and Persistence . 1 edn , vol. 1 , 3 , Springer Polar Sciences,

Springer International Publishing AG , Cham , pp. 23-40 . https://doi.org/10.1007/978-3-030-05523-3_3

http://hdl.handle.net/10138/322142

https://doi.org/10.1007/978-3-030-05523-3_3

unspecified

acceptedVersion

Downloaded from Helda, University of Helsinki institutional repository.

This is an electronic reprint of the original article.

This reprint may differ from the original in pagination and typographic detail.

Please cite the original version. 


\section{European fantasy of the Arctic region and the rise of indigenous Sámi voices in the global arena \\ Reetta Toivanen, University of Helsinki}

\section{Abstract}

In $325 \mathrm{BC}$ the great Greek explorer Pytheas of Massalia travelled in the north of Scandinavia and wrote about the place where the sun never goes to sleep. His stories told about a sublime territory, cold and harsh, inhabited by an isolated, "backwards" people whose lives were shrouded with mystique. Since then, being so far away from civilisation, an imposed and dominating narrative took form in Europe about the region now called Lapland and the North Calotte. The place also became imagined as a cornucopia: a place of immense richness. In many ways, this narrative still lingers today. With examples from the Finnish context, this article argues, that the indigenous peoples of the Arctic are, still centuries after the voyages of Pytheas, the object of a European fantasy. They are framed as guardians of the treasure chest that is the Arctic and as an ancient people of "nature' rather than "culture" and thus doomed to the unpolitical. They are all too rarely given agency. Still today, the states do not listen to their voices. However, the Sámi in the Arctic have today carved out another path to political leverage. They have taken part in the global narrative of indigenous resistance against the conquest and oppression by their states. This article presents examples from the Finnish context, where this global discourse has helped Sámi in Finland to reach the global centers of power in New York and Geneva and gain leverage with the state on land right issues. Adopting this global discourse however, requires indigenous minorities to adopt a specific narrative of "minority-ness"; it requires emphasis on unity and homogeneity and a history of violent conquest, even though the Sámi both historically and contemporarily are more complex and diverse than that. The adoption of this discursive strategy exemplifies the dialectic between disaster and triumph that lies in the core interest of this volume; finding the trail of success through a story of disaster. However, one can still ask on whose terms this current trail is cut out and who it will benefit in the end. Is it the states or the indigenous peoples?

\section{Introduction: European imaginaries about Lapland and its inhabitants}

The Greek explorer Pytheas of Massalia travelled in the north of Scandinavia around the same time when Alexander the Great conquered the world in the south (McPhail, 2014). It has been estimated that Pytheas was, if ever, conducting his travels around $325 \mathrm{BC}$. Later paraphrasers of his now lost work told about a land surrounded by ice where the sun never sets (Chevallier, 1984; Duffy, 2013, p. 125). The accounts of Pytheas' voyages influenced the stories told about to Arctic for centuries to come (Nansen, 2012, p. 44). The Arctic was for long an area which functioned as a "blank canvas upon which the European imagination could project sublime territories and beings", as Duffy (2013, p. 125-126) describes it. It was "shrouded in mystery" into the late 19th century (Ibid.).

Since then, there has been a great variation of stories and myths about the region now called Lapland and the North Calotte, located in the northernmost parts of Norway, Sweden, 
Finland and Russia. Most of them, however, imagine these areas as the periphery of Europe, a remote, harsh and unforgiving environment, often depicted as "primitive" (Bærenholdt \& Granås, 2008). Finnish Lapland has long been depicted as a place of terrifying Noids, witches that could change their embodiment to beasts (Pentikäinen, 1995, p. 160-169). These old stories depicted a people of the wilderness who lived in total isolation and poverty.

Still today, many stereotypical depictions of the Sámi include ideas of a nature people and as exotic and mystic (Ridanpää, 2015). The Sámi are still today often depicted as a northern "people of nature", ancient and traditional as opposed to the binaries of culture and modernity (Ridanpää, 2007; Ryall, Schimanski \& Waerp 2010; Valkonen \& Valkonen, 2014). This has in many instances placed the Sámi on the outside of "culture" and "politics" of states and as having no agency (Baglo, 2014; Nickul, 1984; Pääkkönen, 2008, p. 211-212). Nature does not do politics; it just goes on its natural course. Scholars have subsequently suggested that this imaginary of the Arctic and its people could be called "Arcticism", in a similar manner to Edward Said’s (1978) “Orientalism” (e.g. Ridanpää 2007; Ryall, Waerp \& Schimanski, 2010).

The Nordic states have, also on their part, managed to create an international image as the benign caretakers of the Sámi. Sámi history is presented in a manner in which Sámi people are depicted as nature people who depend on the kindness of the Nordic states (Toivanen, 2003).

Up until the 1960s, also the academic interest with indigenous peoples has been on myths, cosmologies, languages and human-animal relations. There is still plenty of scholarship researching these questions. Indigenous peoples and their languages, cultures, traditions, systems of belief, cosmologies, use of plants or relationships with nature, have for the most part been merely an object of study. The focus has primarily been on victimhood in global and state politics within a frame of colonialism, while agency and more nuanced histories of cultural meetings and local politics have been ignored (Baglo, 2014).

\section{The Arctic as a treasure chest and indigenous peoples as the protectors of nature}

Even though the North was imagined as a sublime and dangerous place, it was also seen as a 'cornucopia' (from the latin term cornu copiae, a horn of plenty) and "a resource frontier" (Steinberg, Tasch \& Gerhardt, 2015, p. 16). The map below by Olaus Magnus, a bishop who travelled as in Scandinavia in order to accomplish a map which would describe the life in the Arctic area, is fuelled with imagination of beasts and fantasies of the North. However, one can also depict vessels of transport and business as well as several churches. Lapland of that time was far from being an isolated place. It was another central region of the world and several 
routes of business crossed it. The two poles of the narrative, possibilities and threats, were present already then (Figure 1).

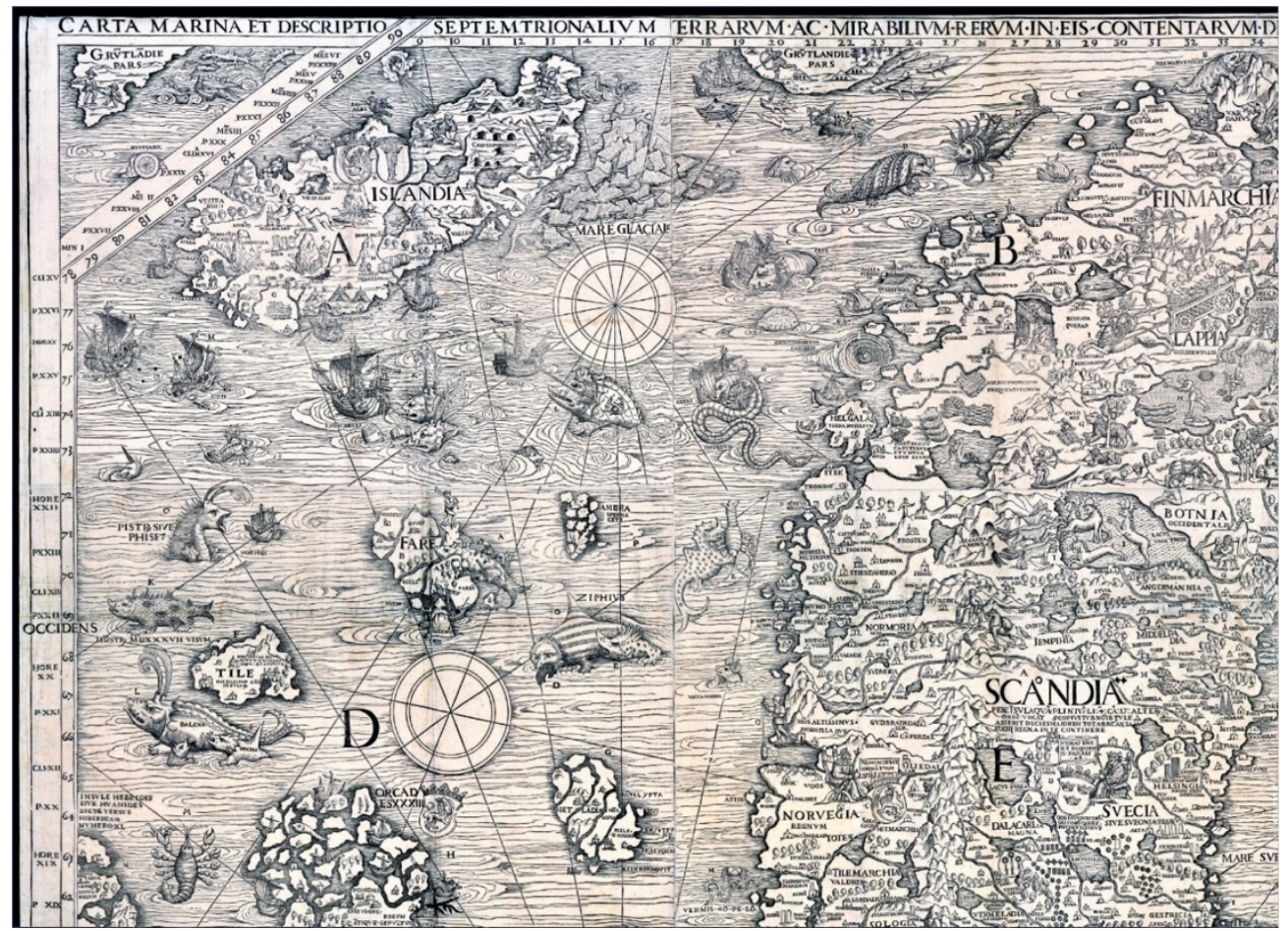

Figure 1. Map by Olaus Magnus: Carta Marina, 1539.

This imaginary remains still today in many respects; the Arctic is of increasing interest to extractive industries (Arbo et al., 2013; Valkonen, 2003, Wilson \& Stammler, 2016; see the governmental reports Growth from the North - How can Norway, Sweden and Finland achieve sustainable growth in the Scandinavian Arctic? by Husebekk, Andersson \& Penttilä, 2015 and For an Ambitious EU Arctic and Northern Policy by Lipponen, 2015). Forest, water, minerals, oil, gas, and vegetation are all of high economic value and much wanted by governments and transnational companies (Arbo et al., 2013; Wilson \& Stammler, 2016). Due to exploitation, large areas traditionally occupied by indigenous peoples have turned into unviable wastelands. The waters have been dammed and polluted, forests have been cut and mines have forced people to leave their traditional homes (see Mustonen et al., 2010).

Private global actors are increasingly present on state lands prompting some authors to speak of an incoming or already ongoing land rush (e.g. Arbo et al., 2013). The effects of extractive industries raise concerns for the harm they cause to Arctic environments and local lands and communities (Jokinen, 2014; Valkonen, 2003, p. 197-198, Wilson \& Stammler, 2016). Local and indigenous culture and livelihoods; fishing, hunting, gathering and reindeer herding - are highly dependent on land, and it goes without saying that contemporary extractive 
activities are a great threat to them today (Daes, 2005; Jokinen, 2014; Revelin, 2013; Schanche, 2001).

Stammler \& Ivanova (2016) use the concept "utilitarian logic": a discursive frame in which natural environments are seen as only of instrumental value - for humans to use for resources. This is a common discourse for international extractive enterprises and states alike, also in the case of Finnish Lapland and the Arctic (Arbo et al., 2013; Valkonen, 2003). This utilitarian approach as part of modern state politics is often found dichotomous to indigenous peoples' cosmologies (Stammler \& Ivanova, 2016): West versus Arctic, ancient versus modern, natural versus political, indigenous cosmology versus western consumerism and individualism and so forth (Pääkkönen, 2008, p. 211-212; Valkonen \& Valkonen, 2014). Today there is an ongoing discursive change regarding the need to preserve the natural environment and to use nature sustainably. Globally and in Finland indigenous peoples have gained a central function in this discourse (Jokinen, 2014; Schanche, 2001; Valkonen \& Valkonen, 2014). "Nature" has come to provide an aspect in the political identity projects of indigenous peoples. In the fight for rights to their lands, being a people of the nature provides a "greater moral right" than others to use their traditional lands (Valkonen \& Valkonen, 2014, p. 35). This discursive function has also been utilised by environmental movements which use it in their quest to protect vulnerable environments. For example, Greenpeace in Finland has often collaborated with Sámi activists in their fight against extractive industries in the Arctic areas of Finland. The website Valitse Metsät [Choose Forests], (accessible at https://metsat.greenpeace.fi [last visited October 1, 2018]) demonstrates this collaboration (see also Jokinen, 2014). In the global discourse, the Sámi, along with other indigenous peoples, have gained a special role as having knowledge of sustainable use of nature (Schanche, 2001, Valkonen, 2003, p. 178, 190; Valkonen \& Valkonen, 2014, p. 34-35). This discourse is also prominent for example in the program Saamelaisten kestävän kehityksen ohjelma [The Sámi program for sustainable development] issued by the Sámi Parliament in Finland in 2006.

The dichotomy of the colonising state and economic market powers on the one hand and indigenous peoples on the other is, however, inherently more complex, particularly with regard to the actual local experiences of extractive projects. As Wilson \& Stammler (2016) point out, extractive industries often induce hope for economic prosperity and jobs in Arctic areas where the economic situation is often critical: for example, in Finnish Lapland the unemployment rate is $13 \%$ in comparison with the national average of $6,5 \%$ while in villages it can be over 25\% (Statistics Finland, Labour force survey, August 2018, accessible at 
https://www.stat.fi/til/tym_en.html [last visited September 15, 2018]. However, even though hope is often raised, many extractive industries are highly risky since markets fluctuate and are hard to predict. Many forms of extractive projects are not long-term solutions; mines are exhausted and waters go dry of fish. A survey done in Finnish Lapland on local peoples' attitudes towards extractive industries showed that local people who identified as non-Sámi were more positive towards new extractive projects (Jokinen, 2014). This result is, however, statistical and Jokinen (2014) points out, that there are many diverging attitudes also among those who identify as Sámi: some were highly positive towards the consequences of extractive industries on their lives. Furthermore, sustainable use of nature has gained value also in the utilitarian discourse. Jokinen (2014) and Hallikainen et al. (2008) point out, that "un-touched" nature is also seen as having economic value today: nature tourism and also nature livelihoods such as fishing and reindeer herding are a big part of the economic viability of many communities in Lapland today, both for Sámi and non-Sámi inhabitants. For example, Jokinen (2014) points out, that sustainable use of forests is even believed to create more jobs than extractive industries. Thus, a straightforward dichotomy of sustainability versus economic profit or of indigenous peoples versus extractive industries is difficult to uphold (see also Wilson \& Stammler, 2016).

The success of adopting a utilitarian versus a "nature people" approach when opposing state and enterprise extractivism diverges. Stammler \& Ivanova (2016) found in their study of Arctic local populations and extractive projects that the local populations which had managed to adopt a "utilitarian logic" were those that managed to make the best deals for themselves when extractive industries entered their lands. On the other hand, cases from Finland show that in collaboration with international organisations such as Greenpeace, Sámi communities have managed to put international pressure on industries that want to save their reputation given that nature conservation and sustainability are highly valued norms today (Jokinen, 2014). However, being labelled as a traditional "nature people" causes further difficulties to include contemporary ways of conducting Sámi livelihoods. For example, Valkonen (2003, p. 191192) demonstrates the contradictions that Sámi face when arguing for their rights to develop reindeer herding while making it a viable industry by the use of "modern technology" such as snow mobiles. The inclusion of modern technology seem to clash in the public discourse with the arguments of "traditionalism" and the "natural universe" into which Sámi culture and livelihoods are situated. 
Indigenous peoples' ways of life are not a historical curiosity. Already in 1994, the Human Rights Committee of the United Nations confirmed that traditionality and modernity are reconcilable (UN, 1994, Länsman et al. vs Finland). Their livelihoods are strongly connected to the vitality of their cultures and languages, to their well-being today and to their survival in the modern world. After all, the subject matter of debate circles around livelihoods which have adapted to strongly changing environments and which have "survived" until the present day through the waves and by the help of modernisation.

\section{Sámi gaining political leverage: The rise of Sámi global rights discourse \& gaining voice in land right issues}

Indigenous people's rights slowly took form in post-war Europe, and during the 1960's indigenous movements around the world started to unite (as well described in Saul, 2016). The Nordic Saami Council was established in 1956 and it also participated in the establishment of the World Council of Indigenous Peoples (Eidheim, 1997). At the same time, in international law, the legal category "indigenous people" took form, and became the core of legal protection for indigenous peoples all around the world (see Niezen, 2003). The definition of the category and the answer to the question "Who is indigenous?" is however frequently still debated. The internationally rather widely acknowledged criteria include that the indigenous peoples must have lived in the area before a state was established, have maintained a specific way of life, social structure, livelihoods, habits, traditions, culture and language distinct from the majority population. The moral basis for granting these special differentiated rights is, however, that all indigenous peoples have suffered under political circumstances during which their cultures, languages, religions or beliefs, livelihoods and the spaces for their livelihoods have been compromised or even destroyed on behalf of religious missionaries, state geopolitics, military interventions and wars (see Deschenes, 1985; United Nations, 2009, p. 1) and, last but not least, due to extractive industries (see Anaya, 2011).

Indigenous peoples have consequently gained leverage in their claims for their lands. Extractive industries are themselves becoming more ethically informed also when it comes to the rights of local communities and indigenous peoples (Wilson \& Stammler, 2016). The Arctic Council has played a central role in the process (Arbo et al., 2013). The several international legal frameworks for the right of indigenous peoples to maintain and foster their culture provide a legal basis for the protection of indigenous peoples lands today (Schanche, 2001). For example, the EU Commission and High Representative of the Union for Foreign Affairs and 
Security Policy (2016, p. 7) in their proposal regarding further developments of the EU's policy towards the Arctic state that "the EU is ready to work with the Arctic states, indigenous peoples and relevant Arctic regional and multilateral fora to share experience, expertise and information on climate change, impacts, adaptation and resilience".

Also the Akwé: Kon Voluntary Guidelines for the Conduct of Cultural, Environmental and Social Impact Assessments Regarding Developments Proposed to Take Place on, or which are Likely to Impact on, Sacred Sites and on Lands and Waters Traditionally Occupied or Used by Indigenous and Local Communities (Secretariat of the Convention on Biological Diversity, 2004) as part of the Convention on Biological Diversity requires that all state plans, also those that further the economies of the state, have to be based on the needs and views of indigenous peoples.

For example, the Finnish state owned company Metsähallitus (2013) published guiding principles for their actions based on the Akwé:Kon guidelines in 2013. They now apply the Akwé: Kon guidelines on all their plans in the Sámi homeland region. The guidelines today state, that before any project can be carried out, there should be detailed and comprehensive impact assessment done in collaboration with Sámi.

Furthermore, UN resolution 17/4 on human rights and transnational corporations and other business enterprises, adopted without a vote in 2011, is based on the Report by $\mathrm{Mr}$. Ruggie's Guiding Principles on Business and Human Rights (UN, 2011). Also the Arctic states' governments have adopted action plans to ensure its full realisation. According to the UN resolution, states have the responsibility to protect their inhabitants from human rights violations by companies and businesses. States are thus responsible for their protection as well as for remedies while companies which do not carry out cultural, environmental and social impact assessments should not be allowed to operate in these countries.

Who are the Arctic indigenous peoples who are protected by these frameworks today? Only 4 million people live in the Arctic region and approximately $10 \%$ of them belong to one of 40 different indigenous peoples, depending on how they are defined (Arctic Centre, 2018). Apart from Sámi who live in Finland, Sweden, Norway and Northwest Russia, also Nenets, Khanty and Evenk in Russia, Inuit (Inuvialuit) in Canada, Inuit (Kalaallit) on Greenland and Inuit (Iñupiat), Aleut and Yupik in Alaska are some of the indigenous peoples in the region (Ibid.; see Ethnologue, 2018). What then is different with Arctic indigenous peoples when compared with indigenous peoples of other regions of the world? The process of colonialisation was different in the European North when compared, for example, with the indigenas of Latin 
America or the Indian tribes of North America. In the Arctic region of the Nordic countries, archaeological and historical linguistic investigations show that the history of inhabitation has not only been that of brutal and violent conquest (Carpelan, 1996; Lehtola, 2012, p. 15-17; Semb, 2001). Rather, the Arctic indigenous peoples of today are a mixture of diverging population histories. New people have arrived and partly acquired the livelihoods of those already there: hunting, fishing and gathering. Simultaneously, the earlier inhabitants have partly adapted to the livelihoods of the newcomers, such as small-scale agriculture and slashand-burn agriculture. For example Lehtola (2012, p. 29-30) argues that Sámi language, livelihoods and cultures were diverse and partly isolated from each other, partly engaged in conflict, and partly mixed with each other at the turn of the $20^{\text {th }}$ century. He argues that at least during the $19^{\text {th }}$ century, one cannot yet talk of a unified Sámi identity or cause. The colonisation history of indigenous peoples can therefore, according to Lehtola (2012, p. 29-30), not solely be seen as a straightforward global story of violent conquest. Instead, it has complex regional and local variations.

As I argue elsewhere, however, the claims of Sámi and all other indigenous peoples still rest on this unified narrative of nature people, homogenous, traditional, and ancient with a unified voice, even if this does not comply completely with neither history nor current diverse and modern ways of being Sámi (see Toivanen 2001; 2003; 2004).

The main national representative organ for Sámi today is the Sámi Parliament, the main institution through which their voices are being heard. Such parliament exists in Norway, Sweden and Finland respectively. The Russian Sámi parliament is still rather an NGO than a state-financed institution (Overland \& Berg-Nordlie, 2012). However, it was the Nordic Council that ignited the need for Sámi Parliaments, and further urged these separate national institutions to form a common, cross-border Sámi Council in order to gain full membership in the Nordic Council (Toivanen, 2003, p. 214), which also represents the Sámi in the Arctic Council. Therefore, the Sámi Parliaments are not natural institutions which would have any historical similarity with the siida-system of self-governing villages (Toivanen, 2007). The Sámi Parliament is rather an invention by the Nordic governments fulfilling a need for a partner for discussion. This a primary example for what Bell (1999) calls "mimesis": the imitation of hegemonic societal structures and discourses in order to get vulnerable communities' voices heard and ensure cultural protection. Even though there is clear research evidence that communities are socially and legally constructed through struggles for rights and resources 
(Coombe, 2011; Huizenga, 2018), policy makers and NGOs alike seem to deploy the term 'community' as a primordial, naturally given structure.

Korpijaakko-Labba (1989) argues that also Sámi have had forms of land ownership before the state incorporated their lands. Their historiography depicts Sámi ancestors as rational landowners with an individualistic way of life, who did not form a closed ethnic group but were always cultural hybrids in the modern sense, which does not fit into the picture of "global indigeneity" (Toivanen, 2003; 2016). However, this is often neglected in a rights discourse where Sámi are "given" land rights and not that land rights that had already existed are being ensured (Schanche, 2001). This is yet another way, in which imagining Sámi as having only a "natural" and given relationship to nature and the environment, has enabled state powers to rule out the "political" when protecting the "nature peoples". It is important to engage with these two opposing postulates in order to identify the influence of the dominant historicism that is elementary to power. This structural power imbalance has helped to keep the Sámi movement at the periphery of modern politics, and entrusted the Sámi Parliaments with cultural but no economic or substantial political autonomy. Thus, the role of the Nordic states in producing a canon of Sámi history has been double-edged: by stressing the harmony in which the Sámi encounter their environment and the disinterest in ownership battles while, at the same time, underlining the distinctiveness of the ethnic group called 'Sámi', it has been easy for the states to declare the forest and fjeld land of Lapland as state property (Korpijaakko-Labba, 1989). One could thus suggest that this is still an example of indigenous people being framed as a naturalised people, doomed to the unpolitical.

What then does these discourses of indigeneity and Sámi mean for their political leverage today? In the next section I demonstrate, first, how I believe that Finnish Sámi, concerning land rights issues, are still not listened to by the state and, second, how their power today lies in surpassing the state and finding another international discursive field for their voices.

\section{Are Sámi heard by the Finnish government today?}

From a perspective of international law and international human rights law, it is without any doubt clear that the development of the Arctic area should take place according to the wishes and needs of the local and indigenous peoples. But is this factually the case? And what do the local people in Finnish Lapland think regarding the consideration of their concerns? 
Based on a survey done for my research in three Arctic municipalities in the Barents Sea area, Porsanger in Norway, Lovozero in the Russian Federation and Inari in Finland, 1-9\% responded that they trust the Finnish or Norwegian parliaments or the Russian Duma to understand their local concerns. The typical answer in my interviews was, that the people from the South have simply no interest in the fact that there are people living in the Arctic area (see also Jokinen, 2014). They have the experience that when MPs in Oslo, Helsinki and Moscow spread their fantasies about the Northern Sea Route, they do not take into account that their plans might affect human beings, not to speak of entire cultures. They only talk about these new maritime routes, rail routes and harbours as responses to the global market. Climate change in this discourse is partly seen as an enabler, as it opens up new shipping pathways in the Arctic.

Let us now look at public discourse on extractive issues in the Arctic. Rather recently, a group of experts, on behalf of the governments of Finland, Sweden and Norway, issued a report with a very telling name: Growth from the North - How can Norway, Sweden and Finland achieve sustainable growth in the Scandinavian Arctic? (Husebekk, Andersson \& Penttilä, 2015). Already the title constructs the states as active subjects and the Arctic as an object from which they can retrieve treasures. The report frames the need for emancipation of local communities and indigenous peoples in the Arctic as follows:

"We believe that sustainable growth in the High North is a prerequisite for sustainable communities - and vice versa. Without investment and new growing businesses in various sectors there will be no jobs, no houses being built, no ground for communities to flourish. And without flourishing communities our Scandinavian Arctic will become an empty husk, a treasury of resources to be emptied or a vast nature reserve with little significance to people and development outside the region. If we truly want to see the Scandinavian Arctic as part of our future success stories, then both sustainable growth and sustainable communities are needed" (Husebekk Andersson \& Penttilä, 2015, p. 12).

In a very telling way, the report argues in this example, that the North is helped only in order for it to help "us". The Arctic is turned into a treasury of resources, and a "part of our future success stories". In this equation, the thriving of local populations has a mere instrumental value: it needs to be protected in order to keep the lands and its treasures sustained. The extract above also depicts the Arctic as an area under the threat of disaster: of becoming an empty treasure chest. The report further emphasises the "uncertainties" of the North when stating that "[t]he potential for sustainable growth in the Arctic is great, but there are significant uncertainties as well" (Ibid., p. 9). The report further explains, that Arctic growth is facilitated primarily through business cooperation with the neighbouring countries, without which 
development is not possible. The companies must join forces to build power lines, roads and hotels, and develop mining technologies in all three countries. Indigenous peoples are scarcely referred to in the report and they are merely mentioned as parties of the "open dialogue" the report aims for (Ibid., p. 18).

Another example is from a report issued by Former Prime Minister of Finland, Paavo Lipponen, who was commissioned to write a report reflecting the EU's interest to become a member of Arctic Council and the role of Finland in this process. The report A Strategic Vision for the North - Finland's prospects for economic growth in the Arctic Region (Lipponen, 2015) mentions Sámi peoples twice: In rather laconic style, the report says that the Sámi peoples' and NGO's possibility to influence have to be secured. None of his 10 key recommendations has anything to do with the people living in the Arctic area.

Another issue related to getting local and Sámi voices heard in Finnish Lapland today is related to regionality. In Figure 2 below, one can see how the former areas of Sámi home territory has shrunk over the course of just a few decades. The southernmost line, the light green area, shows the reindeer herding area in Finland. In this area, reindeer herding is allowed regardless of land ownership or right of possession according to $\S 3$ of the Reindeer Husbandry Act (848/1990). In these areas reindeer herding has traditionally been a livelihood. According to the Reindeer Husbandry Act (848/1990) § 53, the state has to consult reindeer herders in the hole reindeer herding area when land use plans are made which may have an significant impact on reindeer herding.

The black line (Figure 2), above the southern line of the reindeer herding area, indicates the area north of which the traditional Sámi villages, the siidas, existed. The dark green area above that line, is the area specifically intended for reindeer herding. According to $\S 2$ of the Reindeer Husbandry Act (848/1990), the lands in this area are not allowed to be used in ways which can significantly harm reindeer herding. Also according to the Mining Act (621/2011), reindeer herders in the area specifically intended for reindeer herding have to be consulted before mining can take place.

The yellow area (Figure 2) shows the Sámi homeland area, where the Sámi today have self-governance in matters of language and culture. The Finnish Ministry of the Environment (Ympäristöministeriö, 2011) has ruled, that land use in the Sámi homeland area should follow the voluntary guidelines of Akwé: kon. For example, the state owned company Metsähallitus (2013, formerly the Forest and Park Service), has to consult the Sámi Parliament before allowing forestry to take place in the Sámi homeland area. Even though the emphasis in the 
guidelines are on the protection of Sámi culture and language, also "local communities" are mentioned in the guidelines. As Koivurova et al. (2015) show, the Sámi homeland area has quite high protection against mining projects. As the mining registry upheld by the Finnish Safety and Chemicals Agency (accessible at http://gtkdata.gtk.fi/kaivosrekisteri/ [last visited October 1, 2018]) shows, just a little bit south of the Sámi homeland area there is geographically an extensive increase in mining and several reservations for future mining. At the same time, this is the area where many people who self-identify as indigenous peoples live but without any kind of protection or nobody to convey their concerns to those in power. By thus pushing the "Sámi territory" north, the state has managed to gain the highest say in areas which have traditionally been used by Sámi, and where many Sámi still today live.

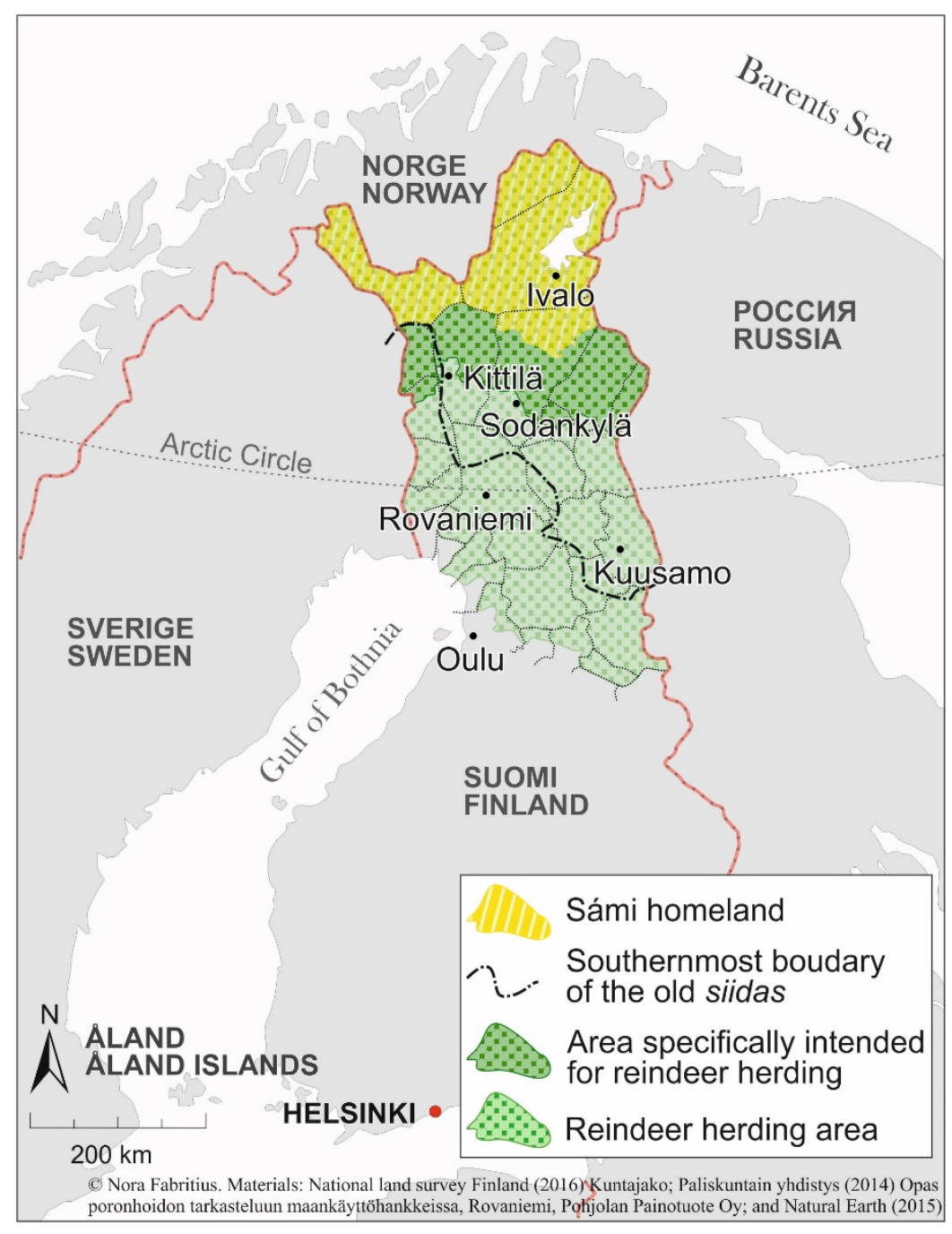

Figure 2. Map of the current administrative areas related to Sámi rights in Finland. 


\section{Learning the correct vocabulary - a case study}

During my ethnographic work in different regions on the Barents Sea area, it has become clear that the only way for Sámi today to get their voices heard is by adopting the international discourse of human rights and the international discourse of indigeneity. It needs to be said that it is a very effective way to raise a voice through the United Nations mechanisms and through international human rights and environmental NGOs. To demonstrate this translation of legal concepts a real-life situation from Inari, Finland, serves as a case study.

Elias (pseudonym) is a reindeer herder in Inari, in Upper Lapland in Finland. He does not make his living solely on reindeer herding, but it constitutes an important part of his salary. He and his brothers are some of the last members of the indigenous people of Sámi who feed their reindeer only naturally which means that they do not feed them additional hay and forage. In 2005, the Finnish Forest industry company Metsähallitus planned to cut down the trees in a forest that was an excellent winter grazing area for Elias' reindeer herds. Elias aired his protest to the municipal authorities and in the local public. As he did not receive any sufficient support, he aired his complain directly to Metsähallitus and in the Ministry for Agriculture. Finally he sought legal solution at the local court. He did not only find support among other Sámi people but especially among other indigenous people in Canada and the USA, among environmental activists of Greenpeace but also among academics and artists.

He protested against a decision by Metsähallitus to cut down forests on an important winter-grazing area, which, since the forest was needed for traditional Sámi reindeer herding, was from his perspective an impossible decision. At first, unfairness lay at the core of his arguments. He stressed that the decision would be inherently unfair since it would endanger his livelihood and the traditional Sámi way of living. He referred to the Finnish constitution that guarantees special rights and protection to the Sámi as an indigenous people, and to the law on cultural autonomy enacted in 1995 . He argued that if he was no longer able to feed his reindeer in a traditional manner naturally, this would mean that his right to living based on his traditions as Sámi would be denied. When he received more and more external support for his matter, his argument and the arguments used by his supporters started to shift slightly but significantly: his matter of concern was now formulated in a language of universal human rights and the emphasis was now placed on the matter that it was his human right as a member was fighting against the forest industry, his reindeer cooperative - and administrative unit - 
decided that he has too many reindeers and his reindeers should be slaughtered. He felt that the cooperative did not understand his way of "natural reindeer breeding" which did not include additional feeding of hey to the animals in winter and therefore argued that he was treated unfairly and wrong.

Notably, when basing his arguments on (un)fairness his possibilities to be heard at the local, national and international arenas were meagre. $\mathrm{s}$. This was quite the opposite when he used a human rights-based argumentation: he received the attention of the UN Special Rapporteur on indigenous matters, Rodolfo Stavenhagen, and the expert of the UN Secretary General for Human Rights, Hina Jilani, both wrote a letter to the Finnish government in which they inquired what Finland plans to do about the forced slaughter. Also the Finnish League for Human Rights took the position that Elias and his brothers should be protected. The feeling of unfairness did not change but as a consequence followed by the interaction with human rights organisations and activists did change the way in which Elias from now on argued his case.

What led to this change in the line of argumentation? Greenpeace, lawyers of the Sámi Parliament, his friends from other first nations in Canada and others taught him another way of protesting, a way that was much more effective and ultimately more triumphant way than writing to local authorities or newspapers: when the protest was formulated in human rights language, it became very effective. To reinterpret experiences and feelings of wrong treatment and unfair codes of conduct means that the personal, individual experience is carried over to an institutionalised and regulated framework of interpretation - one has to take distance to the own agenda, give up those experiences for which there is no legal basis in the human rights discourse and stress those experiences where the articles of the human rights treaties find words.

\section{Conclusion: A new narrative of emancipation or still an imposed imaginary?}

The case of Elias, the reindeer herder, fighting against the powerful forest industry company in order to guarantee his livelihood shows that an experience of unfairness, when translated into another language, namely to the language of human rights, obtains a new meaning and weight. The judicially pre-structured conditions decide in a way, which aspects of the given experience should be stressed.

To conclude, the fantasies about the Arctic, how the indigenous peoples of the Arctic are or should be, are part of a grand narrative of Arctic lives. The indigenous peoples of the Arctic were forced to start talking and even thinking of themselves in terms that may be totally contradictory to what they really are and wish to be. The international discourse on indigenous 
peoples' rights is, of course, on the one side the story of advancing human rights and a story of emancipation. On the other hand, however, the indigenous peoples of the North have come to accept the politics of representation that stresses their internal homogeneity, ties them to a narrative of history that represents them as a people who have lived in total isolation, with unchanged livelihoods, one culture and one language. They are confided in imaginaries of "the nature people". This is of course not to say that nature and lands are not integral to Sámi and local people's lives and culture - they are. However, new ways of being Sámi on the individual's terms are being limited.

Who is fostering these kind of constraints? For example in the Nordic countries and in Russia, the narrative emphasises reindeer herding as a key profession of Sámi (even though merely ca. 5\% of Sámi are reindeer herders). Sámi peoples actually never were one people. The need to speak with one voice, the need to show cultural and even mental unity, is just another form of cultural colonialisation: it was the Nordic states that pushed for establishing Sámi institutions such as parliaments in order to have an institutional counterpart. It was in case of Finland of great state interest to shrink the home area of Sámi to such a small area. Now when we have an on-going debate on who has the right to call herself or himself Sámi in Finland, very few Sámi activists realise that also this debate or friction was brought to them from outside. So, to be allowed to be Sámi and represent the Sámi, you have to please the dominant stereotypes on how Sámi are.

Human rights are a legal framework of hope for fairness and justice. Yet they are prone to be exploited for misuse. This is because they are not born out of a vacuum but also within the strongest interests of prevailing governments. After all, it is states that are to implement/monitor international human rights law. Human rights law cannot not easily be separated from international politics (Koskeniemi, 2011). As Elenius (2008) argues, the Cap of the North also bears cases of internal colonialism in the post-colonial sense: these structures are visible in the discursive tug of war between different local interests, between minority movements and states, between the local and global, and between the states as well as international institutions. I argue that this is something that should be paid attention to: it was the policies of Nordic countries towards Sámi populations, influenced by international standards of minority rights that essentialised and homogenised the diverse Sámi cultures. Creating an image of the homogeneous, group-centred, and changeless nature of the pre-modern Sámi society made them eligible for the rights of indigenous people. However, the global identity project called 
'indigeneity' has induced local tensions and conflicts around the question of who is allowed to embrace this global name.

The indigenous movement is becoming stronger and at the same time increasingly more global. Due to the unprecedented level of modern communication, indigenous populations around the world are uniting and acting in a concerted fashion. The links between groups separated by borders of states, are now accessible via high speed internet, at least for those who share a common language. This evokes a belief in post-nation states politics and to sovereignty that a peoples, such as Sámi living in four different countries, could reach together. However, already in 1995 Jeff Corntassel and Tomas Hopkins Primeau (1995, p. 363) wrote on indigenous sovereignty, that "[c]o-opting the term sovereignty to fit indigenous perspectives of autonomous freedom has done far more harm than good." Why is this?

In my research this boils down to the paradox of rights: The establishment of Sámi parliaments, cultural and language autonomies, different (hundreds) paragraphs in legislation, policy programs etc. seem like a grand story of emancipation of a people, a nation. Even so, one can be still with reason sceptical regarding whether this is the whole story or whether it should be interpreted as part of majority power, control and their invitation to imitate the nation state's structures.

This is one special danger in the field of minority rights and in the field of rights of indigenous peoples; those who have best served the agenda of those in power: adapted to the right forms of self-representation and gained a self-evident place for representing the minority, may be blind (innocently) or ignorant (with purpose) for minorities inside they "group". The reason being that they try so hard to please the expectations that governing diversity and accepting the unknown unknowns (Chandler, 2014, p. 50). This becomes untenable: they fear that accepting a more heterogeneous form of group would endanger all the rights gained today. Whereas one can ask whether the indigenous peoples' rights discourse have managed to emancipate the people they aim to protect, it must be acknowledged that the internationalization of the indigenous agenda, as described in this article, has given representatives or activists of indigenous peoples unpreceded power to go against the governments of the countries they live in. According my observation, for example in Finland, the people working in the ministries are clearly afraid of upsetting the Sámi Parliament because this has already many times led to the intervention by the UN Special Rapporteur of Indigenous Issues or by other international institutions. 


\section{References}

Anaya, J. (2011). Report of the Special Rapporteur on the rights of indigenous peoples, James Anaya: Extractive industries operating within or near indigenous territories. Report A/HRC/18/35. http://unsr.jamesanaya.org/annual-reports/report-to-the-human-rights-councila-hrc-18-35-11-july-2011. Accessed 15 Oct 2018.

Arbo, P., Iversen, A., Knol, M., Ringholm, T., \& Sander, G. (2013). Arctic futures:

Conceptualizations and images of a changing arctic. Polar Geography, 36(3), 163-182.

Arctic Centre (2018) Arctic indigenous peoples.

https://www.arcticcentre.org/EN/communications/arcticregion/Arctic-Indigenous-Peoples. Accessed 8 Oct 2018.

Baglo, C. (2014). Rethinking Sami Agency during Living Exhibitions. In L. Graham \& H.G. Penny (Eds) Performing Indigeneity: Global Histories and Contemporary Experiences (pp. 136168). London: University of Nebraska Press.

Bell, V. (1999). Mimesis as Cultural Survival: Judith Butler and Anti-Semitism. Theory, Culture \& Society, 16(2), 133-161.

Bærenholdt, J.O. \& Granås, B. (2008). Places and Mobilities Beyond the Periphery. In J.O. Barenholdt \& B. Granas (Eds.) Mobility and place: enacting Northern European peripheries. Cornwall: Ashgate Publishing.

Carpelan, C. (1996). Mikä on alkuperämme (What is our origin?). Hiidenkivi, 4(96), 10-14.

Chandler, D. (2014). Beyond neoliberalism: resilience, the new art of governing complexity. Resilience, 2(1), 47-63.

Chevallier, R. (1984). The Greco-Roman Conception of the North from Pytheas to Tacitus. Arctic, 37(4), 341-346.

Coombe, R. (2011). Cultural Agencies: 'Constructing' Community Subjects and Their Rights. In M. Biagioli, P. Jaszi, M. Woodmansee, (Eds) Making and Unmaking Intellectual Property (pp. 79-98). Chicago: University of Chicago Press.

Corntassel, J. J. \& Primeau Hopkins, T. (1995). Indigenous "Sovereignty" and International Law: Revised Strategies for Pursuing "Self-Determination". Human Rights Quarterly, 17(2), 343365

Daes, E-I., A. (2005). Indigenous Peoples' Rights to Land and Natural Resources. In N. Ghanea \& A. Xanthaki (Eds) Minorities, Peoples, and Self-determination: Essays in Honour of Patrick Thornberry (pp.75-91). Leiden: Martinus Nijhoff Publishers.

Deschênes, J. (1985). Proposal concerning a definition of the term "minority". United Nations Document E/CN.4/Sub.2/1985/31. https://digitallibrary.un.org/record/88267. Accessed 15 Oct 2018.

Duffy, C. (2013). The Landscapes of the Sublime, 1700-1830, UK: Palgrave Macmillan.

Eidheim, H. (1997). Ethno-political development among the Sami after World War II: The invention of selfhood. In H.Gaski (Ed.) Sami culture in a new era: The Norwegian Sami experience (pp.29-61) Kárášjohka: Davvi Girji OS.

Elenius, L. (2008). Postmodernt identitetsskapande på Nordkalotten (Post-modern identityconstruction on the North Calotte). In P. Sköld (Ed.) Människor i Norr: Sámisk forskning på nya vägar (People in the North: Sámi research on new trails) (pp. 509-522). Umeå: Umeå University.

Ethnologue (2018) Ethnologue. https://www.ethnologue.com. Accessed 26 Aug 2018.

EU Commission and High Representative of the Union for Foreign Affairs and Security Policy (2016) Joint communication to the European Parliament and the Council: An integrated European Union Policy for the Arctic.

http://eeas.europa.eu/archives/docs/arctic_region/docs/160427 joint-communication-anintegrated-european-union-policy-for-the-arctic_en.pdf. Accessed 15 Oct 2018. 
Hallikainen, V., Helle, T., Hyppönen, M., Ikonen, A., Jokinen, M., Naskali, A., Tuulentie, S., Varmola, M. (2008). Luonnon käyttöön perustuvat elinkeinot ja niiden väliset suhteet YläLapissa (Nature-based livelihoods and relationships between them in Northern Lapland). Metsätieteen aikakauskirja 3, 191-219.

Huizenga, D. (2018). Articulations of Aboriginal title, indigenous rights, and living customary law in South Africa. Socio \& Legal Studies 27(1), 3-24.

Husebekk, A., Andersson, M., Penttilä. R.E.J. (2015). Growth from the North. How can Norway, Sweden and Finland achieve sustainable growth in the Scandinavian Arctic? Report of an independent expert group. Helsinki: Prime Minister's Office.

https://valtioneuvosto.fi/documents/10616/1095776/J0415_Growth+from+the+North_net.pdf 2613b2d6-96f8-4ca1-813a-658eaad7f858. Accessed Oct 82018.

Jokinen, M. (2014) Heated and frozen forest conflicts: Cultural sustainability and forest management in arctic Finland. In P. Katila, G. Galloway, W. de Jong, P. Pacheco, G. Mery (Eds) Forests under pressure: Local responses to global issues (pp. 381-399). Vienna: International Union of Forest Research Organisations.

Koivurova, T., Masloboev, V., Hossain, K., Nygaard, V., Petrétei, A., Vinogradova, S. (2015). Legal Protection of Sami Traditional Livelihoods from the Adverse Impacts of Mining: A Comparison of the Level of Protection Enjoyed by Sami in Their Four Home States. Arctic Review, 6(1). doi:10.17585/arctic.v6.76.

Korpijaakko-Labba, K. (1989). Saamelaisten oikeusasemasta Ruotsi-Suomessa: oikeushistoriallinen tutkimus Länsi-Pohjan Lapin maankäyttöoloista ja-oikeuksista ennen 1700-luvun puoliväliä (On the legal status of Sámi in Sweden-Finland: a legal history study of land use and land rights in Länsi-Pohja in Lapland before mid 18th century), Helsinki:Lakimiesliiton kustannus.

Koskeniemi, M. (2011). Human Rights, Politics, and Love. In Koskeniemi, M. (ed) The politics of international law (pp. 153-168). Oxford: Hart Publishing.

Lehtola, V. (2012). Saamelaiset suomalaiset: Kohtaamisia 1896-1953 (Sámi Finns: Encounters 1896-1953), Helsinki: Suomalaisen Kirjallisuuden Seura.

Lipponen, P. (2015). A Strategic Vision for the North - Finland's prospects for economic growth in the Arctic Region. https://ek.fi/wp-content/uploads/A-Strategic-Vision-for-the-North.pdf. Accessed 15 Oct 2018.

McPhail, C. (2014). Pytheas of Massalia's route of travel. Phoenix, 68(3/4), 247-257.

Metsähallitus (2013). Toimintamalli Akwé: Kon- ohjeiden soveltamisesta Metsähallituksessa (Operations model for the implementation of the Akwé:Kon guidelines in Metsähallitus). MH 4975/2013/00.01. https://api.hankeikkuna.fi/asiakirjat/ed23c4c1-2313-439f-aa073dc647d25917/f7fd8469-1a9d-4bd0-9c26-c6557d16b570/KIRJE_20131127093251.pdf. Accessed 13 Sept 2018.

Mining Act (621/2011) https://www.finlex.fi/fi/laki/kaannokset/2011/en20110621.pdf. Accessed 15 Oct 2018 .

Mustonen, K., Mustonen, T., Aikio, A., Aikio, P. (2010). Drowning Reindeer, Drowning Homes: Indigenous Sámi and Hydroelectricity Development in Sompio, Finland, Vaasa: Snowchange.

Nansen, F. (2012). In Northern Mists: Arctic Exploration in Early Times, London: Ballantyne Press.

Nickul, K. (1984). Onko saamelaisilla tulevaisuutta (Do Sámi have a future?). In J. Helander, M. Mykkänen, E. Nickul, T. Salo, L. Sammallahti (Eds) Bálggis. Polku. Sámi Čuvgehussearvi 1932-1982 Lapin Sivistysseura (pp. 45-50). Jyväskylä: Gummerous.

Niezen, R. (2003). The Origins of Indigenism: Human Rights and the Politics of Identity, California: University of California Press.

Overland, I. \& Berg-Nordlie, M. (2012). Bridging Divides Ethno-political Leadership among the Russian Sámi, Oxford: Berghahn Publisher. 
Pentikäinen, J. (1995). Saamelaiset: Pohjoisen kansan mytologia (Sámi: The mythology of the people of the North), Helsinki: Suomalaisen Kirjallisuuden Seura.

Pääkkönen, E. (2008). Saamelainen etnisyys ja pohjoinen paikallisuus: Saamelaisten etninen mobilisaatio ja paikallisperustainen vastaliike (Sámi ethnicity and northern localness, the ethnic mobilisation of Sámi and local movements of resistance), Rovaniemi: Lapin yliopistokustannus.

Reindeer Husbandry Act (848/1990). https://www.finlex.fi/fi/laki/kaannokset/1990/en19900848_20000054.pdf. Accessed 15 Oct 2018.

Revelin, F. (2013). Ecotourism and extraction in Saami lands: Contradictions and continuities. In B. Büscher \& V. Davidov (Eds) The Ecotourism and Extraction Nexus: Rural realities and Political Economies of (Un) comfortable bedfellows (pp. 193-214). Oxon: Routledge.

Ridanpää, J. (2007). Laughing at northernness: Postcolonialism and metafictive irony in the imaginative geography. Social \& Cultural Geography, 8, 907-928.

Ridanpää, J. (2015). 'Singing acts' from the deep North: critical perspectives on northern exotics, contemporary ethnic music and language preservation in Sámi communities. Journal for Cultural Research, 20(1), 17-30.

Ryall, A., Schimanski, J., Wærp, H. H. (2010). Arctic discourses: an introduction. In A. Ryall, J. Schimanski, H.H. Wærp (Eds.) Arctic discourses (pp.ix-xxiii). UK: Cambridge Scholars Publishing.

Said, E.W. (1978). Orientalism: Western conceptions of the orient, London: Routledge.

Sámi Parliament (2006) Saamelaisten kestävän kehityksen ohjelma (The Sámi Program for Sustainable Development). http://www.ym.fi/download/noname/\%7B463A8622-2BC043AD-AE4D-C0F70B3C2F85\%7D/27643. Accessed 8 Oct 2018.

Saul, B. (2016). Indigenous Peoples Human Rights: International and Regional Jurisprudence, Oxford: Hart Publishing.

Schanche, A. (2001). Innledning. Naturresurser og miljöverider I samiske områder: forvaltnings- og forskningutfordringer (Introduction: Natural resources and environmental values in Sámi territories: challenges in administration and research). Diedut (2), 3-19.

Secretariat of the Convention on Biological Diversity (2004). Akwé: Kon. Voluntary guidelines for the conduct of cultural, environmental and social impact assessments regarding developments proposed to take place on, or which are likely to impact on, sacred sites and on lands and waters traditionally occupied or used by indigenous and local communities. Secretariat of the Convention on Biological Diversity. https://www.cbd.int/doc/publications/akwe-brochureen.pdf. Accessed 15 Oct 2018.

Semb, A.J. (2001). How Norms Affect Policy - The Case of Sami Policy in Norway. International Journal on Minority and Group Rights, 8(2-3), 177-222.

Stammler, F., \& Ivanova, A. (2016). Confrontation, coexistence or co-ignorance? Negotiating human-resource relations in two Russian regions. The Extractive Industries and Society, 3(1), 60-72.

Steinberg, P.E., Tasch, J., Gerhardt, H. (Eds.). (2015). Contesting the Arctic: Politics and imaginaries in the circumpolar North, London: I.B. Tauris.

Toivanen, R. (2001). Minority rights and minority identities-Sámi in Finland and Sorbs in Germany. Finnish Yearbook of Population Research, 37, 83-102.

Toivanen, R. (2003). The Saami People and Nordic Civil Society. In N. Götz \& J. Hackmann (Eds) Civil Society in the Baltic Sea Region (pp. 205-216), Aldershot: Ashgate.

Toivanen, R. (2004). Anthropology and the Paradox of Rights in a Multicultural Context. In V. Puuronen, A. Häkkinen, A. Pylkkänen, T. Sandlund, R. Toivanen (Eds) New Challenges for the Welfare Society (pp. 107-123). Joensuu: University of Joensuu \& Karelian Institute. 
Toivanen, R. (2016). Localising the Global in the Superdiverse Municipalities of the Arctic: The Case of Inari. In R. Toivanen \& J. Saarikivi (Eds) Linguistic Genocide Or Superdiversity?: New and Old Language Diversities (pp. 221-247). Bristol: Multilingual Matters.

United Nations (1994). Länsman et al. v. Finland, Communication No. 511/1992. United Nations Document CCPR/C/52/D/511/1992 (1994). https://www.escrnet.org/sites/default/files/HR\%27s_Committee_Decision_0.html. Accessed 8 Oct 2018.

United Nations (2009). State of the World's Indigenous Peoples, New York: United Nations Publications.

United Nations (2011). Guiding Principles on Business and Human Rights: Implementing the United Nations 'Protect, Respect and Remedy' Framework. The Human Rights Council endorsed the Guiding Principles in its resolution 17/4 of 16 June 2011. United Nations document $\mathrm{HR} / \mathrm{PUB} / 11 / 04$.

https://www.ohchr.org/Documents/Publications/GuidingPrinciplesBusinessHR_EN.pdf. Accessed 15 Oct 2018.

Valkonen, J. (2003). Lapin luontopolitiikka: Analyysi vuosien 1946-2000 julkisesta keskustelusta (The politics of nature in Lapland: An analysis of the public discussion during the years 1946-2000), Tampere: Tampereen yliopisto.

Valkonen, J., \& Valkonen, S. (2014). Contesting the nature relations of Sámi culture. Acta Borealia, 31(1), 25-40.

Wilson, E., \& Stammler, F. (2016). Beyond extractivism and alternative cosmologies: Arctic communities and extractive industries in uncertain times. The Extractive Industries and Society, 3(1), 1-8.

Ympäristöministeriö (2011). Akwé: Kon -ohjeet. (Akwé:Kon Guidelines). http://julkaisut.valtioneuvosto.fi/bitstream/handle/10138/41525/OH1_2011_Akwe_Kon_ohjeet.pdf?sequence $=2$. Accessed 8 Oct 2018. 